\title{
Do Global Trade Distortions Still Harm Developing Country Farmers?
}

\author{
Kym Anderson and Ernesto Valenzuela*
}

\author{
Development Research Group \\ The World Bank \\ 1818 H Street NW \\ Washington DC 20433 \\ kanderson@worldbank.org \\ evalenzuela1@worldbank.org
}

\begin{abstract}
World Bank Policy Research Working Paper 3901, April 2006
The Policy Research Working Paper Series disseminates the findings of work in progress to encourage the exchange of ideas about development issues. An objective of the series is to get the findings out quickly, even if the presentations are less than fully polished. The papers carry the names of the authors and should be cited accordingly. The findings, interpretations, and conclusions expressed in this paper are entirely those of the authors. They do not necessarily represent the view of the World Bank, its Executive Directors, or the countries they represent. Policy Research Working Papers are available online at http://econ.worldbank.org.
\end{abstract}

*This is a product of the World Bank's project on Poverty Alleviation Through Reducing Distortions to Agricultural Incentives. The authors are grateful for helpful comments from project participants and referees, and for funding from BNPP and DFID Trust Funds from the Dutch and British governments. 


\begin{abstract}
We estimate the impact of global merchandise trade distortions and services regulations on agricultural value added in various countries. Using the latest versions of the GTAP database and the GTAP-AGR model of the global economy, our results suggest real net farm incomes would rise in developing countries with a move to free trade, thereby alleviating rural poverty - despite a terms of trade deterioration for developing countries that are net food importers or are enjoying preferential access to agricultural markets of high-income countries. We also show, for several large developing countries, the contribution of their own versus other countries' trade policies.
\end{abstract}

\title{
JEL codes: C68, D58, F17, Q17
}

Key words: Trade policy reform, CGE modeling, agricultural markets, economic welfare

\section{Contact author:}

Kym Anderson

Development Research Group

The World Bank

Mailstop MC3-303

1818 H Street NW

Washington DC 20433 USA

Phone +1 2024733387

Fax +12025221159

kanderson@worldbank.org 


\section{Do Global Trade Distortions Still Harm Developing Country Farmers?}

While developing country farmers contribute less than 3 percent of global GDP, they account for 43 percent of global employment, 64 percent of global agricultural value added, and a similarly large share of global poverty as measured by earnings of less than \$1 a day. Raising net farm incomes is therefore a key to meeting the Millennium Development Goal of halving global poverty by 2015. If that can be done by policy reforms that also boost the efficiency of resource use and raise developing country and world GDP, so much the better. This paper asks if reducing trade policy distortions (including agricultural subsidies in high-income countries) could provide such a magic bullet.

Two decades ago, the answer to that question was unequivocally affirmative. A number of studies provided a clear picture of the adverse effects of government policies on farmers' incentives in developing countries in the 1980s. Farm subsidies and import restrictions of developed countries depressed the international prices of farm relative to non-farm products (Tyers and Anderson 1986, 1992), while developing countries’ own trade and exchange rate policies further depressed their farmers’ incentives (Krueger, Schiff and Valdes 1988) - as they had since at least the 1960s (Little, Scitovsky and Scott 1970; Balassa and Associates 1971). Time series data for developed and newly industrializing countries up to that time also indicated a clear tendency for national governments to gradually change from taxing to subsidizing agricultural relative to industrial production (and from subsidizing to taxing food consumers) in the course of their economic development (Anderson and Hayami 1986, Lindert 1991). Had that 
tendency continued, today's developing country farmers would be even more adversely affected by richer countries’ policies.

However, several developments since the mid-1980s have altered the policy environment. First, the World Trade Organization's Uruguay Round Agreement on Agriculture -- negotiated over the period 1986-94 and implemented in the subsequent ten years -- slowed and in some cases reversed the growth in agricultural protection. Second, recent accessions to WTO (especially of China and Taiwan from early 2002) added to the commitments to limit agricultural tariffs and subsidies. Third, early this decade developed countries expanded non-reciprocal preferential access to their markets for developing country exports, notably via the Africa Growth and Opportunity Act adopted by the US Congress in 2000 and the 'Everything But Arms' initiative in 2001 by the European Union (which added to EU preferences provided to former colonies in Africa, the Caribbean and the Pacific under the Lome Convention). Meanwhile, many developing countries themselves have opted to reduce their own disincentives against their farmers, as part of overall structural adjustments encouraged by international lending institutions (World Bank 2002).

Given these policy developments, is it still the case that developing country farmers are discriminated against by the patterns of trade distortions across sectors and regions? By the mid-1990s it appeared to one group of analysts that, for the sample of fifteen developing countries they examined, the problem of an anti-agricultural bias in those countries' own trade and sectoral policies had all but disappeared (Jensen, Robinson and Tarp 2002). Even if we assume the price distortions used in that study were a true reflection of policy distortions at that time, is its sample of countries 
representative of all developing countries? Are there, for example, some moreadvanced developing countries that have 'overshot' and adopted the potentially equally wasteful pro-agricultural policy bias of high-income economies? And how are those high-income countries' somewhat-reformed policies and preferential access agreements now affecting developing country farmers?

To answer all but the last of those questions requires extending the time series of estimates of distortions in the Krueger/Schiff/Valdes sample and expanding theirs and the Jensen/Robinson/Tarp sample to a wider range of countries. That is the focus of a new research project getting under way at the World Bank.

As a prelude to that new project, though, it is possible to answer the question in the title of the present paper using a new database for 2001 at least. Specifically, the present paper addresses two questions. First, what would be the consequences for agricultural value added (net farm incomes) if all countries were to remove their trade distortions simultaneously (as in an ideal WTO round), as distinct from just reducing their own distortions? While no-one anticipates such a radical reform, the analysis can serve as a benchmark to suggest what is at stake in the WTO's current round of multilateral trade negotiations (Anderson and Martin 2005, 2006). The second question addressed below is: for a selection of large developing countries and Sub-Saharan Africa, what contribution would their own unilateral reform make to the impact on net farm incomes of global reform? ${ }^{1}$

1 The Krueger, Schiff and Valdes (1988) and Jensen, Robinson and Tarp (2002) studies focused on effects of just own-country policies, the first using partial equilibrium and the second using national general equilibrium models. On the relationship between those two methodologies, and for reasons as to why the latter is superior in principle, see Bautista, Robinson, Wobst and Tarp (2001). 
Specifically, we make use of a new variant of a model of the global economy known as GTAP-AGR (Keeney and Hertel 2005) to provide real farm income effects of moving to free trade by developing countries versus by high-income countries, and in agriculture as compared with non-agricultural sectors. We also make use of the latest GTAP database (Version 6), which has the virtue of including not only reciprocal but also non-reciprocal preferential tariffs, the latter providing exporters in many lowincome countries with duty-free access to protected high-income country markets. This allows us to take into account the fact that such a reform may cause a decline in the international terms of trade for those developing countries that are enjoying preferential access to agricultural markets of high-income countries (in addition to those that are net food importers because their comparative advantage is in other sectors such as laborintensive manufacturing).

The paper begins with an examination of current distortions, the emphasis being mainly on import tariffs since they are later shown to be far more important than agricultural subsidies. This is followed by a description of GTAP-AGR model of the global economy to be used to analyze the consequences of removing those distortions. The key results of the simulations are then presented, distinguishing between the impacts of policies of high-income and developing countries, of agricultural and nonagricultural (including services) policies and, within agriculture, of the different policy instruments and the different commodity programs. The paper concludes by highlighting the key messages and suggestion priority areas for further research.

\section{Key distortions in global markets}


Border measures traditionally have been the main means by which governments distort prices in their domestic markets for products, with the price of tradables relative to nontradables affected by interventions in the market for foreign exchange, and the relative prices of the various tradables affected by trade taxes-cum-subsidies or quantitative trade restrictions. Product-specific domestic producer or consumer subsidies have played a more limited role (because of their much greater cost to the treasury), with a few exceptions most notably in agriculture in high-income countries (Legg 2003; OECD 2005a). With the freeing up of most foreign exchange markets over the past two decades (Hinkle and Montiel 1999), the phasing out of most export taxes (Piermartini 2004; Theile 2004), and the conversion of many non-tariff trade barriers into tariffs including for farm products (Ingco 1996), the task of measuring the extent of distortions to goods markets is made much easier in that attention can focus on import tariffs and OECD agricultural subsidies. Services regulations also could distort incentives in the agricultural and industrial sectors, so it is worth exploring their effects on farm income too -- although much controversy still surrounds their measurement and how they should be modeled.

The latest release of the GTAP dataset, Version 6, includes estimates of bilateral tariffs and of domestic and export subsidies as of 2001 for 87 countries and country groups spanning the world, and for 57 aggregated sectors of the economy. This is a substantial improvement over Version 5 of the GTAP dataset, which relates to policies in 1997. The new protection data come from a joint CEPII (Paris)/ITC (Geneva) project. The product of this joint effort, known as MAcMaps, provides HS6 tariff level 
details on bilateral tariffs (incorporating all significant reciprocal and non-reciprocal preferences) including ad valorem tariff equivalents of specific and compound tariffs and key non-tariff barriers such as tariff rate quotas (TRQs). ${ }^{2}$ The new GTAP database has lower tariffs than the previous Version 5 database because of the inclusion for the first time of non-reciprocal trade preferences and because of major reforms between 1997 and 2001 such as China’s progress towards WTO accession (which alone contributed to the ratio of global exports plus imports to GDP rising from 44 to 46 percent over those four years) and the continued implementation of the Uruguay Round agreements (van der Mensbrugghe 2006).

According to this dataset, the average import tariff in high-income countries in 2001 is 20.2 percent for primary agricultural products, and 13.0 percent for processed food, compared with just 0.5 percent for other primary products and 2.1 percent for other manufactures. ${ }^{3}$ In developing countries, by contrast, the average tariff for primary agriculture is lower at 17.0 percent, while it is higher for the other three sectors at 19.3 percent for processed food, 2.5 percent for other primary products, and 10.0 for other manufactures. Needless to say, these averages vary considerably within those two country groups, as shown in Table 1(a).

These import tariff averages can be poor indicators of overall assistance to farming, even if there were no farm production or trade subsidies or any exceptional tax

2 More information on the MAcMaps database is available in Bouët et al. (2004) and at http://www.cepii.fr/anglaisgraph/bdd/macmap.htm. For details of its incorporation into the GTAP Version 6 dataset, see Dimaranan and McDougall (2005) and www.gtap.org.

3 High-income countries include all members of the EU25, NAFTA and the OECD (except Turkey) plus Hong Kong, Singapore and Taiwan. All others (including the wealthy Middle East countries) are considered developing countries and are further split into middle- and low-income categories as defined at the bottom of Appendix Table A1. 
treatment for the sector. For example, if high-income countries' import tariffs are at near-prohibitive levels for temperate farm products but are low for tropical products such as coffee, their import-weighted average agricultural tariff could be quite low yet agricultural value added in those rich countries would have been enhanced substantially. Consider also the case of a developing country with a strong agricultural comparative advantage in all but one small farming industry, and with high tariffs to reduce import competition for that industry and for all manufacturing industries. Overall agricultural value added would be depressed by that structure of protection, yet the import-weighted average tariff protection for agriculture would be high and possibly above that for manufactures. A third case is where the non-agricultural primary sector receives a similar level of import protection as the farm sector and less than the manufacturing sector, but is much more export-focused than agriculture: trade reform may cause it to expand at the expense not only of manufacturing but also of farming. Hence it is not possible to say from the tariff data in Table 1(a) alone whether developing country policies now have a pro-agricultural bias, even though the ratio of agricultural to all goods tariffs in that table is well above unity for each of the regions shown. What is needed is a general equilibrium model to estimate the net effects of own and other countries' various sectoral distortions on agricultural markets and net farm income. The latter impact, on agricultural value added, is a measure of the global general equilibrium effective rate of assistance to the primary agricultural sector, a portion of which is attributable to own-country policies. ${ }^{4}$

4 This approach is similar to that taken by Dihel (2004) except that only own-country policies are considered in that study. 
Before turning to that model, the Version 6 GTAP database needs to be augmented to include distortions to services sectors. ${ }^{5}$ We follow Hertel and Keeney (2006) in assuming the removal of services distortions can be modeled as a technological change that reduces the cost to all sectors of imported intermediate inputs. The extent of those trade cost equivalent barriers in services are based on work by Francois, Meijl, and Tongeren (2005), who draw on the pattern of residuals from a gravity model of national imports estimated from the GTAP database. Their estimates are shown in Table 2.

\section{The GTAP-AGR Model}

We employ a new variant of the widely used GTAP model (Hertel 1997) that is specifically oriented to analyzing agricultural markets, namely the GTAP-AGR model (Keeney and Hertel 2005). We use the standard GTAP model assumptions of perfect competition and constant returns to scale in production activities, a Constant Difference of Elasticities (CDE) demand system which permits differential price and income responsiveness across countries, and bilateral international trade flows handled through Armington elasticities by which products are differentiated by country of origin. ${ }^{6}$ These Armington elasticities are region-specific, and are econometric estimates at the 57

5 We also insert a production subsidy for US cotton, following the WTO dispute settlement case which ruled that those subsidies belong in the Uruguay Round Agreement on Agriculture's amber box, rather than in the green box as notified by the US. We conservatively estimate that subsidy to be 28 percent for 2001 .

6 The Armington elasticities are very important determinants of the results, and those used in the GTAP model are quite conservative compared with those in, for example, the World Bank's Linkage model (see the Appendix to Ch. 12 in Anderson and Martin 2006). For this reason, the key results in this paper can be considered lower-bound estimates. 
GTAP commodity level based on the elasticity of substitution in consumption among imported goods from different sources (Hertel et al. 2003).

The GTAP-AGR model introduces a number of modifications to the way agriculture is handled in the standard GTAP model, based on recent econometric studies. First, it incorporates a region-specific elasticity of land transformation amongst agriculture uses. While land is specific to agriculture in the GTAP model, the new parameters in GTAP-AGR make land less responsive within the agricultural sector to changes in relative agriculture prices. Second, GTAP-AGR incorporates region-specific labor and capital supply elasticities in constant elasticity of transformation functions that allocate their use between agricultural and non-agricultural sectors. The limited mobility of labor allows for wage differentials between agriculture and non-agricultural sectors, and capital too is allowed to receive return differentials between agricultural and non-agricultural activities. These supply elasticities are based on estimates from the OECD (2001). Third, the GTAP-AGR model also allows for substitution among farmowned and purchased inputs, and between the two, by calibrating each sector's constant elasticity of substitution cost function to the region-specific Allen elasticities of substitution provided by OECD estimates. Fourth, the livestock production function is modified to capture more realistic substitution possibilities in feed demand, by modeling the substitution possibilities for feedstuffs as an additional CES nest in the sector's cost function. This livestock production function is parameterized based on a three-stage model describing the behavior of European livestock producers, composite feed mixers, and grain producers (Surry 1990). Finally, the GTAP-AGR consumer demand system is re-specified assuming separability of food from non-food 
commodities, and calibrated in line with a recent set of price and income elasticities from a cross-country study (Seale, Regmi and Bernstein 2003). ${ }^{7}$

In the simulations that follow, we use the standard GTAP closure. This assumes that the levels of each region's employment of each of the productive factors is fixed in aggregate, and that the regional balance of trade is determined by the relationship of regional investment and savings, where international capital mobility is determined by equalizing rates of return across regions.

To keep the sizes of the table of results reasonable, we aggregate the GTAP 6 database to 27 regions and 29 sectors, bearing in mind the need to provide some detail in the agri-food sectors. These regions and sectors are listed in Appendix Tables A1 and A2, respectively.

\section{Effects of removing distortive goods and services policies globally}

The estimated effects of full global trade liberalization as of 2001 on each of the four sectors' value added are summarized for the key developing country regions in Table 3 and are shown with more country detail for just agricultural value added in Table 4. Beginning with the top right-hand numbers of Table 3, these results suggest real farm incomes in developing countries are still harmed by the existing pattern of global trade distortions, and more so than any of the other goods sectors (non-

While one of the benefits of using a global general equilibrium framework is the modeling of all economic agents' behaviors, and in this case also the depiction of some specifics of agricultural markets in the GTAP-AGR model, the results necessarily depend on the parameters chosen. A natural validation of the model is to see how well the model is able to replicate historical records. Support for the use of the GTAP-AGR model is provided by Valenzuela (2006) who shows that the model replicates reasonably well historical wheat price variability in world markets. 
agricultural primary production, food processing, and other manufacturing) and therefore than non-agriculture in total. In the absence of those policies, agricultural value added would have been 5.7 percent higher on average, and higher in each of the six developing country regions shown in that table relative to non-agriculture in total (compare with the numbers in parentheses in the final column of Table 3). There is considerable regional variation though: the averages are 12 percent higher in Latin America, 10 percent higher in East Asia (excluding Korea and Taiwan which, with Hong Kong and Singapore, we classify as high-income), 3 percent higher in SubSaharan Africa, and less than 2 percent higher in the three other developing country regions.

Turning to the top left-hand numbers of Table 3 , it is clear that most of that gain to developing country farmers would come from the removal of agricultural tariffs and subsidies in high-income countries. ${ }^{8}$ Net farm incomes in all developing country regions, even those that are net food importers and those receiving preferential access to protected markets in high-income countries, would be boosted by such reform. By contrast, according to the GTAP Version 6 database and GTAP-AGR model used here, agricultural value added in all developing country regions would be reduced by the reform of agricultural and food policies in developing countries themselves. This is not surprising, given the high protection to agriculture in both high-income and developing countries reported in Table 1(a). Columns 3 and 4 of Table 3 show that loss would be partly offset by reform in non-agricultural sectors though, with services reform making

8 Decomposition of those results reveals that more than two-thirds of the gains to developing country farm incomes from high-income country agricultural policy reform would come from removal of tariffs, and that domestic rather than export subsidies contribute most of the rest. See the discussion of Table 10 below. 
almost as much of a contribution as reform of other goods sectors (and considerably more in Sub-Saharan Africa and South Asia). ${ }^{9}$ This partial offset is consistent with the fact developing countries have tariffs on non-food manufactures that are sizeable but less than those for agriculture, and whose removal has the effect of lowering a little the price of mobile factors employed in farming.

Value added in the processed food sector is similarly affected, although to a lesser extent on average than in the farm sector. Value added in non-agricultural primary production is affected very much less for developing countries as a whole, but note from the final column of Table 3 that it benefits proportionately more than farming in Africa, the Middle East and the former Soviet Union where that sector is of relatively greater importance. By contrast, non-food manufacturing value added would decline in all developing country regions except Asia following a move to global free trade. This is despite its lower protection than agriculture in developing countries, and a further reflection of the importance of high-income country farm support programs in depressing developing country farm incomes.

The differential impacts on net farm incomes within regions from freeing trade are shown in Table 4. In East Asia it is primarily Chinese farming that would benefit while in South Asia, farming is benefited in Pakistan and Sri Lanka rather than in India and Bangladesh. That reflects the latter countries’ relatively weaker comparative

$9 \quad$ The smallness of our estimated contribution of service sector distortions to value added in agricultural and other goods sectors is consistent with the findings of two other recent studies drawing on similar service distortion estimates (Dee 2004; Dihel 2004). Recall, though, that the distortions to the services sector we use (see Table 2) may well seriously underestimate the full extent of actual services distortions. 
advantage in agriculture. ${ }^{10}$ Only in a handful of the developing countries listed (Russia, Bangladesh, India and the Philippines) would farmers be worse off under full reform. In each case this is because of the large negative impact of developing (including their own-) country agricultural and food policy reform.

How important is own-country liberalization as distinct from other countries' liberalization? This is shown in Table 5 for a selection of developing countries. Farmers in Argentina and especially Brazil would gain hugely from high-income agricultural reform and a little from their own and other developing countries' reforms; farmers in China also would gain a lot from high-income country reform but, as for the other developing country regions shown, they would lose a little from own reform; and farmers in South Asia and Sub-Saharan Africa also would lose a little from other developing countries’ reform. In Indonesia and Sub-Saharan Africa, farmers would gain overall from global liberalization; but in Bangladesh and India the farmers' gain from high-income countries' reform is not enough to offset the loss from own and other developing countries' reform - instead it is manufacturing that would gain in those two countries, mainly from own-country reform. In Sub-Saharan Africa, the biggest proportional gain in sectoral value added is in non-agricultural primary activities (three times that for agriculture), mainly from own-country reform, reflecting the strong comparative advantage of non-food primary production in that region.

When the effects of the liberalizations in Table 5 are separated into agricultural and non-agricultural reform, as in Table 6, it is evident that agricultural reform by other

10 As measured by, for example, population density or the share of agriculture in the country's exports relative to agriculture's share of global exports (Balassa's 'revealed' comparative advantage index see Anderson 2002, Table 2.7). 
developing countries reduces the adverse effect on net farm income of own-country agricultural reform (and conversely for non-agricultural liberalization). This illustrates yet again the interdependencies of policies of different countries in our globalized world, and underscores the importance of addressing these distortions in a multilateral forum as provided for by the WTO.

The tariffs reported in Table 1 show import protection in South Asia and SubSaharan Africa to be half as large again in agriculture and food processing as in other manufacturing. Yet careful studies that compare domestic and border prices for some of those countries have found very little actual protection delivered to farmers from import barriers (e.g., Mullen, Orden and Gulati 2005; Martin and Wang 2004), suggesting there may be 'water' in the agricultural tariffs that are included in the GTAP database. What would be the impact of trade reform on net farm incomes if the delivered protection rates to agriculture were in fact zero?

To see how much difference that could make to the results, we re-calibrated the model assuming agricultural tariff protection in 2001 was actually zero in Bangladesh, India, and Sub-Saharan Africa other than South Africa, and then re-ran the full global liberalization simulation. The difference this makes to the net farm income results for those countries, shown in the lower part of Table 6, suggests that the earlier small gain to Sub-Saharan African farmers from global liberalization would nearly quadruple, and the small losses to farmers in Bangladesh and India would switch to a gain of around 4 percent. These simulations underscore the point that the results depend heavily on owncountry agricultural protection rates, which in the current GTAP database are assumed to be fully reflected in the applied import tariff rates and a few producer subsidies in the 
case of developing countries (whereas for high-income countries they are based on the much more thorough estimates of producer support estimates provided by OECD 2005a).

Also, the GTAP database includes only a few export taxes (see Table 1(b)), yet there is evidence that others exist even if they are small in most cases (Piermartini 2004). In Argentina’s case some sizeable ones were re-introduced in 2002 (OECD 2005b, Annex A). To see how much difference they could make to the effects of reform, we re-calibrated the model assuming not only that Argentina’s agricultural tariff protection in 2001 was zero but also that the country had export taxes of 20 percent for cereals, oilseeds and livestock products, 10 percent for other (including nonagricultural) primary products, and 5 percent for other processed food products and other manufacturing. ${ }^{11}$ From that new base we then re-estimated the effects of full unilateral reform. As shown in Table 6, that database amendment makes a huge difference to the impact of unilateral reform on agricultural value added in Argentina. It also raises the estimated impact of reform on non-agricultural value added, mostly because of the boost it gives to food processing. Instead of having just a minor effect, the presence of these new export taxes mean that own-reform by Argentina would boost net incomes of its farmers by a dramatic one-third; and global reform would boost them by more than one-half, instead of an estimated one-fifth as of 2001 before those export taxes were imposed.

11 Based on the Ministry of Economy and Production's resolutions 11/2002, 35/2002, and 532/2004, kindly provided by Maximiliano Mendes-Parra. 
Pending a more-thorough estimation of production and trade taxes and subsidies in developing country, how does the current estimated pattern of distortions (ignoring the amendments discussed above regarding the bottom part of Table 6) affect developing countries' shares of global markets? Their share of all agricultural and food value added would be three percentage points higher at 49 percent if global markets were fully liberalized, and their export share would be five percentage points higher at 40 percent, with the increases being largest for grains, oilseeds, beef, cotton and sugar. These changes for agriculture are much larger than those for other sectors (bottom of Table 7), although other sectors' shares also rise a little as the developing countries' importance in the global economy expands.

The propensity to trade agricultural commodities internationally would rise substantially following global liberalization. This is important because, by thereby 'thickening' international markets, food price fluctuations would be dampened, which would reduce concerns about vulnerability to import dependence. The extent of this global public good aspect of agricultural trade reform can be sensed from the results reported in Table 8. Rice and sugar are especially noteworthy: their global shares of production exported treble and nearly double, respectively - a direct result of the very high protection in those two product markets. For all agricultural and processed food products as a group, the share would rise by one-fifth for the world as a whole, and by almost one-third for developing countries.

The converse of that rise in export propensity is an increase in imports as a share of food consumption as farmers throughout the world specialize more in what they do best. For developing countries as a group that share also rises by nearly one- 
third as consumers adjust their consumption bundle to their income increase and to changes in relative prices (final column of Table 8), suggesting food self-sufficiency would not change much. The latter is confirmed in Table 9: it shows an increase from 101 percent to just 102 percent for all agriculture and food for developing countries. Not surprisingly given the earlier results and underlying protection rates, the biggest rises are in rice and sugar, where self-sufficiency rates rise 5 or 6 percentage points for developing countries.

To what extent are the effects of agricultural policies on net farm incomes due to the three key 'pillars' of agricultural support programs that are explicitly negotiated at the WTO, namely domestic producer subsidies, export subsidies, and import tariffs? As anticipated from Table 1, the first two are economically significant only in highincome countries; and Table 10 confirms that the removal of export subsidies would make almost no contribution to farm incomes on average (the loss in high-income countries being fully offset by the gain to farmers in developing countries). Domestic subsidies and import tariffs are equally important to developing country net farm incomes, each contributing 45 percent of the overall impact of global trade policies on those incomes (see final three columns of Table 10).

In terms of impact on global agricultural trade, the middle row of Table 10 shows that a much bigger 86 percent of the growth that would occur under full reform would come from import expansion - again underlining the relative importance of the market access 'pillar'.

Finally from Table 10, note from the bottom rows that the importance of the market access 'pillar' is even greater for global welfare, with import tariffs accounting 
for a huge 93 percent and domestic and export subsidies just 5 and 2 percent, respectively. ${ }^{12}$ This difference is partly explained by the fact that trade measures are a tax on consumers, in addition to boosting value added for producers. So, unlike direct domestic farm subsidies which only affect consumers via small second-round effects insofar as they alter international food prices, trade measures doubly harm national welfare.

How do different agricultural commodity programs contribute to the global welfare cost of agricultural and food market distortions? According to our GTAP-AGR model results, rice programs are the most important, followed by beef and oilseeds and then sugar and dairy products (Table 11). High-income policies are responsible for 82 percent of that cost of agricultural and food policies (compared with only 49 percent in the case of policies affecting other manufacturing - see part (b) of Table 11). The extraordinarily high contribution of rice reflects the enormous tariffs and subsidies in that sector in Japan and Korea but also, if to a lesser extent, in other East Asian economies and in the European Union. In addition there is considerable domestic support for US rice producers. Tariffs are high in beef also, together with some export subsidies. Tariffs are somewhat lower in oilseed products, where in high-income countries most support comes from producer subsidies; however in developing countries the oilseed processing sector is protected from import competition, and since those products are a crucial input into livestock industries they add to the adverse

12 For details of the GTAP-AGR model's estimated economic welfare effects of full global trade reform, see Hertel and Keeney (2006). The contribution of export subsidies is small partly because most distortions (notably import tariffs but also export taxes) cause the world to trade less than is optimal globally, so export subsidies offset that tendency. It turns out they are not a full offset though, because they also have inefficient resource allocative effects in the imposing countries. For more on this point see Anderson, Martin and Valenzuela (2006). 
welfare contributions of those industries’ policies as well. Together these results suggest much of the welfare cost of protection globally could be removed if just a few agricultural markets were liberalized.

\section{Conclusions and areas for further research}

The following are the key messages that emerge from our analysis:

- The answer to the question in the title of the paper is yes, in the sense that full global liberalization of goods and services trade would raise net farm income in all six developing country regions, and more than it would raise non-agricultural value added;

- Global liberalization would not raise net farm incomes in each and every developing country, however, with our results suggesting that Bangladesh, India, the Philippines and Russia would be among the exceptions - but only because of their own high agricultural protection rates in the GTAP database;

- With that Version 6 GTAP database, our results are not inconsistent with those of Jensen, Robinson and Tarp (2002) in that for several large developing countries (Bangladesh, China, India, Indonesia), own-country policies help rather than harm agricultural relative to non-agricultural value added, with the harm from own non-agricultural policies being more than offset by help from own agricultural and food policies; and

- Other countries' policies have the opposite effect, of depressing agricultural value added in developing countries, with high-income country policies 
contributing most to that finding notwithstanding the tariff preferences provided to numerous low-income countries.

These results suggest that a multilateral move to global free trade would be good for developing country farmers. Whether that would be true too for a unilateral reform by any particular developing country depends heavily on the extent to which that country's own policies effectively assist or harm that economy’s farm sector relative to its other sectors. Our measures of those effects depend very much on the levels of distortion in the GTAP database we use, as is clear from the sensitivity analysis of results reported above in Table 6. The agricultural distortions for highincome countries are reasonably reliable, thanks in large part to the carefully compiled protection estimates by the OECD (2005a and earlier). Currently available estimates of (particularly agricultural) trade distortions and subsidies in developing countries are less reliable, however. Nor are estimates provided in the GTAP database for all export taxes or tax equivalents of quantitative restrictions and bans on exports by developing countries. A new project at the World Bank is seeking to provide better estimates of that sort, building on the earlier work of Krueger, Schiff and Valdes (1988) and the OECD’s comprehensive PSE methodology and improved methods for measuring of exchange rate misalignment (Hinkle and Montiel 1999). Distortions to factor markets, particularly labor, may also have an important influence on the results for some countries if they were to be included in the model. Even more challenging is the task of improving estimates of distortions to services trade and foreign direct investment. These are the next frontiers in improving our understanding of the impact of policies on agricultural and other sectors' production, trade and value added. Only then will it be 
possible to generate better estimates of the poverty consequences of such reforms, building on Winters (2005) and the pioneering empirical work in Hertel and Winters (2006). 


\section{References}

Anderson, K. (2002), Agricultural Trade Liberalization: Implications for Indian Ocean Rim Countries, Canberra: Department of Foreign Affairs and Trade.

Anderson, K., Y. Hayami and Others (1986), The Political Economy of Agricultural Protection: East Asia in International Perspective, Boston, London and Sydney: Allen and Unwin.

Anderson, K. and W. Martin (2005), 'Agricultural Trade Reform and the Doha Development Agenda’, The World Economy 28(9): 1301-27, September.

Anderson, K. and W. Martin (eds.) (2006), Agricultural Trade Reform and the Doha Development Agenda, London: Palgrave Macmillan and Washington DC: World Bank.

Anderson, K., W. Martin and E.Valenzuela (2006), 'The Relative Importance of Global Agricultural Subsidies and Market Access’, mimeo, World Bank, Washington DC, March.

Balassa, B. and Associates (1971), The Structure of Protection in Developing Countries, Baltimore: Johns Hopkins University Press.

Bautista, R.M., S. Robinson, P. Wobst and F. Tarp (2001), 'Policy Bias and Agriculture: Partial and General Equilibrium Measures', Review of Development Economics 5(1): 89-104, February.

Bouët, A., Y. Decreux, L. Fontagné, S. Jean and D. Laborde (2004), 'A Consistent, ad valorem Equivalent Measure of Applied Protection Across the World: The MAcMap-HS6 Database', mimeo, CEPII, Paris, 20 December.

Dee, P. (2004), 'Economy-Wide Effects of Barriers to Trade in Services in Selected Developing Countries', TD/TC/WP(2004)42/REV1, Trade Directorate, OECD Secretariat, Paris, 13 December.

Dihel, N. (2004), 'Impact of Services Barriers on Effective Rates of protection in Agriculture and Manufacturing', TD/TC/WP(2004)49, Trade Directorate, OECD Secretariat, Paris, 26 November.

Dimaranan, B. and R. McDougall (eds.) (2005), Global Trade, Assistance, and Production: The GTAP 6 Data Base, Center for Global Trade Analysis, Purdue University, West Lafayette.

Francois, J. F., H. van Meijl, and F. van Tongeren (2005), 'Gauging the WTO Negotiation's Potential Gain from the Doha Round', Economic Policy: 349-91, April.

Hertel, T. (ed.) (1997), Global Trade Analysis: Modeling and Applications, Cambridge and New York: Cambridge University Press. 
Hertel, T., D. Hummels, M. Ivanic, and R. Keeney (2003), 'How Confident Can We Be in CGE-Based Assessments of Free Trade Agreements?' GTAP Working Paper No. 26, Center for Global Trade Analysis, Purdue University, West Lafayette.

Hertel, T.W. and R. Keeney (2006), 'What's at Stake: The Relative Importance of Import Barriers, Export Subsidies and Domestic Support', Ch. 2 in Agricultural Trade Reform and the Doha Development Agenda edited by K. Anderson and W. Martin, London: Palgrave Macmillan and Washington DC: World Bank.

Hertel, T.W. and L.A. Winters (eds.) (2006), Putting Development Back Into the Doha Agenda: Poverty Impacts of a WTO Agreement, London: Palgrave Macmillan and Washington DC: World Bank.

Hinkle, L. and J. Montiel (eds.) (1999), Exchange Rate Misalignment: Concepts and Measurement for Developing Countries, New York: Oxford University Press.

Ingco, M.D. (1996), 'Tariffication in the Uruguay Round: How Much Liberalization?' The World Economy 19(4): 425-47, July.

Jensen, H.T., S. Robinson and F. Tarp (2002), 'General Equilibrium Measures of Agricultural Policy Bias in Fifteen Developing Countries', TMD Discussion Paper No. 105, IFPRI, Washington DC, October.

Keeney, R. and T. Hertel (2005), 'GTAP-AGR: A Framework for Assessing the Implications of Multilateral Changes in Agricultural Policies’, GTAP Technical Paper No. 24, Center for Global Trade Analysis, Purdue University, West Lafayette.

Krueger, A.O., M. Schiff and A. Valdes (1988), 'Agricultural Incentives in Developing Countries: Measuring the Effect of Sectoral and Economy-wide Policies', World Bank Economic Review 2(3): 255-72, September.

Legg, W. (2003), ‘Agricultural Subsidies: Measurement and Use in Policy Evaluation’, Journal of Agricultural Economics 54(2): 175-200, July.

Lindert, P. (1991), 'Historical Patterns of Agricultural Protection', in Agriculture and the State, edited by P. Timmer, Ithaca: Cornell University Press.

Little, I.M.D., T. Scitovsky and M. Scott (1970), Industry and Trade in Some Developing Countries: A Comparative Study, London: Oxford University Press.

Martin, W. and Z. Wang (2004), 'The Landscape of World Agricultural Protection', mimeo, The World Bank, Washington DC, May.

Mullen, K., D. Orden and A. Gulati (2005), 'Agricultural Policies in India: Producer Support Estimates 1985-2002’, MTID Discussion paper No. 82, Washington DC: International Food Policy research Institute, February.

OECD (2001), Market Effects of Crop Support Measures, Paris: Organization for Economic Cooperation and Development.

OECD (2005a), Agricultural Policies in OECD Countries: Monitoring and Evaluation 2005, Paris: Organization for Economic Cooperation and Development. 
OECD (2005b), OECD-FAO Agricultural Outlook 2005-2014, Paris: Organization for Economic Cooperation and Development.

Piermartini, R. (2004), 'The Role of Export Taxes in the Field of Primary Commodities', WTO Discussion Paper No. 4, Geneva: World Trade Organization.

Seale, J., A. Regmi, and J. Bernstein (2003) International Evidence on Food Consumption Patterns, ERS Technical Bulletin No.1904, Washington DC: US Department of Agriculture.

Surry, Y. (1990), 'Econometric Modeling of the European Compound Feed Sector: An Application to France', Journal of Agricultural Economics 41: 404-421.

Thiele, R. (2004), 'The Bias Against Agriculture in Sub-Saharan Africa: Has it Survived 20 Years of Structural Adjustment Programs?' Quarterly Journal of International Agriculture 42(1): 5-20.

Tyers, R; and K. Anderson (1986): 'Distortions in World Food Markets: A Quantitative Assessment', Background Paper No. 22 prepared for the World Bank's World Development Report 1986, Washington DC: World Bank.

Tyers, R. and K. Anderson (1992), Disarray in World Food Markets: A Quantitative Assessment, Cambridge and New York: Cambridge University Press.

Valenzuela, E. (2006), Poverty, Vulnerability and Trade Policy in General Equilibrium, Ph.D. Dissertation, Purdue University, West Lafayette.

van der Mensbrugghe, D. (2006), 'Estimating the Benefits: Why Numbers Change', Ch. 4 in Trade, Doha and Development: A Window into the Issues, edited by R. Newfarmer, Washington DC: World Bank.

Winters, L.A. (2005), 'European Agricultural Trade Policies and Poverty’, European Review of Agricultural Economics 32(3): 319-46, September.

World Bank (2002), Global Economic Prospects and the Developing Countries 2002: Making Trade Work for the Poor, Washington DC: The World Bank. 
Table 1(a): Import-weighted average applied import tariffs on goods, by sector and region, 2001

(percent of cif import value)

\begin{tabular}{|c|c|c|c|c|c|}
\hline & $\begin{array}{c}\text { Primary } \\
\text { agriculture }\end{array}$ & $\begin{array}{l}\text { Processed } \\
\text { food }\end{array}$ & $\begin{array}{l}\text { Agric. and } \\
\text { processed } \\
\text { food }\end{array}$ & $\begin{array}{l}\text { Non-ag } \\
\text { primary }^{a}\end{array}$ & $\begin{array}{c}\text { Other } \\
\text { manuf- } \\
\text { acturing }\end{array}$ \\
\hline High-income countries $^{b}$ & 20.2 & 13.0 & 16.0 & 0.5 & 2.1 \\
\hline Australia \& New Zealand & 1.2 & 8.1 & 5.7 & 3.9 & 5.7 \\
\hline United States & 2.3 & 2.6 & 2.5 & 0.0 & 1.9 \\
\hline Canada & 1.2 & 14.4 & 9.1 & 0.0 & 0.9 \\
\hline Mexico & 10.8 & 12.2 & 11.5 & 4.7 & 4.5 \\
\hline European Union (EU15) & 12.4 & 13.2 & 12.8 & 0.1 & 1.8 \\
\hline EU's 10 new entrants & 9.7 & 18.7 & 15.1 & 0.4 & 3.1 \\
\hline European Free Trade Area & 29.6 & 31.3 & 30.7 & 0.1 & 1.9 \\
\hline Japan & 47.7 & 21.8 & 30.2 & 0.1 & 1.7 \\
\hline Korea \& Taiwan & 87.9 & 23.0 & 55.8 & 3.5 & 4.1 \\
\hline Hong Kong \& Singapore & 0.0 & 0.2 & 0.1 & 0.0 & 0.0 \\
\hline Developing countries & 17.0 & 19.3 & 18.1 & 2.5 & 10.0 \\
\hline Middle-income countries & 17.8 & 15.6 & 16.7 & 1.1 & 9.7 \\
\hline Low-income countries & 14.9 & 27.3 & 21.5 & 6.0 & 10.6 \\
\hline E. Europe \& Central Asia & 13.4 & 15.9 & 14.9 & 0.3 & 5.7 \\
\hline Russia & 14.5 & 12.8 & 13.5 & 0.8 & 9.2 \\
\hline Other E. Europe \& C. Asia & 12.5 & 19.1 & 16.1 & 0.3 & 4.1 \\
\hline East Asia \& Pacific & 31.4 & 20.2 & 26.1 & 0.8 & 9.8 \\
\hline China & 49.0 & 18.6 & 37.6 & 0.4 & 12.7 \\
\hline Indonesia & 4.3 & 6.3 & 5.0 & 0.4 & 4.9 \\
\hline Philippines & 14.1 & 6.6 & 9.5 & 3.0 & 2.3 \\
\hline Viet Nam & 12.6 & 44.4 & 36.6 & 3.8 & 14.5 \\
\hline Other East Asia \& Pacific & 17.9 & 26.1 & 22.6 & 0.6 & 6.9 \\
\hline South Asia & 18.0 & 54.7 & 33.9 & 14.5 & 22.7 \\
\hline Bangladesh & 7.5 & 21.1 & 12.6 & 20.0 & 19.8 \\
\hline India & 25.6 & 76.6 & 50.2 & 15.0 & 27.3 \\
\hline Other South Asia & 14.6 & 32.4 & 21.5 & 10.4 & 12.8 \\
\hline Middle East \& North Africa & 9.5 & 18.0 & 13.6 & 3.5 & 9.3 \\
\hline Morocco & 26.5 & 35.5 & 29.3 & 9.0 & 22.0 \\
\hline Other M. East \& N. Africa & 8.3 & 17.4 & 12.8 & 2.5 & 8.7 \\
\hline Sub-Saharan Africa & 15.3 & 20.5 & 18.3 & 2.0 & 12.0 \\
\hline South Africa & 6.1 & 10.9 & 8.9 & 0.0 & 7.0 \\
\hline Other Sub-Saharan Africa & 17.1 & 22.3 & 20.1 & 3.8 & 14.2 \\
\hline Latin America \& Caribbean & 7.1 & 11.1 & 9.5 & 2.0 & 9.7 \\
\hline Argentina & 5.4 & 7.6 & 6.9 & 0.4 & 10.5 \\
\hline Brazil & 2.4 & 9.0 & 5.0 & 0.4 & 10.9 \\
\hline Other Latin America \& Carib. & 9.0 & 11.7 & 10.7 & 3.5 & 9.1 \\
\hline WORLD & 18.9 & 15.0 & 16.8 & 0.9 & 4.2 \\
\hline
\end{tabular}

(continued) 
Table 1(b): Export-weighted average applied export subsidies/taxes on goods, by sector and region, 2001

(percent of fob export value, negatives are export taxes)

\begin{tabular}{|c|c|c|c|c|c|}
\hline & $\begin{array}{l}\text { Primary } \\
\text { agriculture }\end{array}$ & $\begin{array}{l}\text { Processed } \\
\text { food }\end{array}$ & $\begin{array}{l}\text { Agric. and } \\
\text { processed } \\
\text { food }\end{array}$ & $\begin{array}{l}\text { Non-ag } \\
\text { primary }^{a}\end{array}$ & $\begin{array}{c}\text { Other } \\
\text { manuf- } \\
\text { acturing }\end{array}$ \\
\hline High-income countries ${ }^{\mathrm{b}}$ & 1.0 & 3.0 & 2.3 & 0.0 & 0.0 \\
\hline Australia \& New Zealand & 0.0 & 0.0 & 0.0 & -0.5 & -1.1 \\
\hline United States & 0.0 & 0.2 & 0.1 & 0.0 & 0.0 \\
\hline Canada & 0.0 & 0.0 & 0.0 & 0.0 & 0.0 \\
\hline Mexico & 0.0 & 0.0 & 0.0 & 0.0 & 0.0 \\
\hline European Union (EU15) & 6.2 & 8.1 & 7.7 & 0.0 & 0.0 \\
\hline EU's 10 new entrants & 0.2 & 0.8 & 0.6 & 0.0 & 0.0 \\
\hline European Free Trade Area & 4.1 & 3.9 & 3.9 & 0.0 & 0.0 \\
\hline Japan & 0.0 & 0.0 & 0.0 & 0.0 & 0.0 \\
\hline Korea \& Taiwan & 1.8 & 0.0 & 0.4 & 0.0 & -0.1 \\
\hline Hong Kong \& Singapore & 0.0 & 0.0 & 0.0 & 0.0 & -0.2 \\
\hline Developing countries & 0.0 & 0.0 & 0.0 & -1.8 & -1.0 \\
\hline Middle-income countries & 0.1 & 0.0 & 0.0 & -2.2 & -1.2 \\
\hline Low-income countries & 0.0 & 0.0 & 0.0 & -0.2 & -0.8 \\
\hline E. Europe \& Central Asia & 0.0 & 0.0 & 0.0 & -5.7 & -1.4 \\
\hline Russia & 0.0 & 0.0 & 0.0 & -7.6 & -3.2 \\
\hline Other E. Europe \& C. Asia & 0.0 & 0.0 & 0.0 & -0.1 & -0.1 \\
\hline East Asia \& Pacific & 0.0 & 0.0 & 0.0 & -0.1 & -1.1 \\
\hline China & 0.0 & 0.0 & 0.0 & 0.0 & -1.6 \\
\hline Indonesia & 0.0 & 0.0 & 0.0 & 0.0 & -0.9 \\
\hline Philippines & 0.0 & 0.0 & 0.0 & 0.1 & -0.2 \\
\hline Viet Nam & 0.0 & 0.0 & 0.0 & -1.2 & -5.3 \\
\hline Other East Asia \& Pacific & 0.0 & 0.0 & 0.0 & -1.0 & -0.3 \\
\hline South Asia & 0.0 & 0.0 & 0.0 & -0.3 & -2.1 \\
\hline Bangladesh & 0.0 & 0.0 & 0.0 & 0.0 & 0.0 \\
\hline India & 0.0 & 0.0 & 0.0 & 0.0 & -1.6 \\
\hline Other South Asia & 0.0 & 0.0 & 0.0 & -2.1 & -4.4 \\
\hline Middle East \& North Africa & 0.4 & 0.0 & 0.2 & -1.8 & -0.8 \\
\hline Morocco & 0.0 & 0.0 & 0.0 & -2.8 & -2.6 \\
\hline Other M. East \& N. Africa & 0.5 & 0.0 & 0.3 & -1.8 & -0.6 \\
\hline Sub-Saharan Africa & 0.0 & 0.0 & 0.0 & 0.0 & 0.2 \\
\hline South Africa & 0.0 & 0.0 & 0.0 & 0.5 & 0.5 \\
\hline Other Sub-Saharan Africa & 0.0 & 0.0 & 0.0 & -0.2 & -0.2 \\
\hline Latin America \& Caribbean & 0.0 & 0.0 & 0.0 & -0.3 & 0.1 \\
\hline Argentina & 0.0 & 0.0 & 0.0 & -0.7 & -0.5 \\
\hline Brazil & 0.0 & 0.0 & 0.0 & -0.4 & -0.4 \\
\hline Other Latin America \& Carib. & 0.0 & 0.0 & 0.0 & -0.3 & 0.7 \\
\hline
\end{tabular}

(continued) 
Table 1(c): Production-weighted average applied domestic producer subsidies on goods, by sector and region, 2001

(percent of trade-distorted value of production)

\begin{tabular}{|c|c|c|c|c|c|}
\hline & $\begin{array}{l}\text { Primary } \\
\text { agriculture }\end{array}$ & $\begin{array}{l}\text { Processed } \\
\text { food }\end{array}$ & $\begin{array}{l}\text { Agric. and } \\
\text { processed } \\
\text { food }\end{array}$ & $\begin{array}{l}\text { Non-ag } \\
\text { primary }^{\mathrm{a}}\end{array}$ & $\begin{array}{l}\text { Other } \\
\text { manuf- } \\
\text { acturing }\end{array}$ \\
\hline High-income countries $^{b}$ & 11.1 & 0.0 & 3.1 & 0.0 & 0.1 \\
\hline Australia \& New Zealand & 2.3 & 0.0 & 1.0 & 0.0 & 0.0 \\
\hline United States & 13.6 & 0.0 & 3.3 & 0.0 & 0.0 \\
\hline Canada & 9.7 & 0.0 & 3.0 & 0.0 & 0.0 \\
\hline Mexico & 7.6 & 0.0 & 2.2 & 0.0 & 0.0 \\
\hline European Union (EU15) & 15.9 & 0.0 & 4.1 & 0.0 & 0.4 \\
\hline EU's 10 new entrants & 4.8 & 0.0 & 1.5 & 0.0 & 0.0 \\
\hline European Free Trade Area & 34.1 & 0.7 & 7.0 & 0.0 & 0.1 \\
\hline Japan & 3.4 & 0.0 & 1.0 & 0.0 & 0.0 \\
\hline Korea \& Taiwan & 2.0 & 0.0 & 0.9 & 0.0 & 0.0 \\
\hline Hong Kong \& Singapore & 0.0 & 0.0 & 0.0 & 2.9 & 0.0 \\
\hline Developing countries & 0.6 & 0.0 & 0.4 & 0.0 & 0.0 \\
\hline Middle-income countries & 0.1 & 0.0 & 0.1 & 0.0 & 0.0 \\
\hline Low-income countries & 1.4 & 0.0 & 1.0 & 0.0 & 0.1 \\
\hline E. Europe \& Central Asia & 0.1 & 0.0 & 0.1 & 0.0 & 0.0 \\
\hline Russia & 0.0 & 0.0 & 0.0 & 0.0 & 0.0 \\
\hline Other E. Europe \& C. Asia & 0.2 & 0.0 & 0.1 & 0.0 & 0.0 \\
\hline East Asia \& Pacific & 0.0 & 0.0 & 0.0 & 0.0 & 0.0 \\
\hline China & 0.0 & 0.0 & 0.0 & 0.0 & 0.0 \\
\hline Indonesia & 0.0 & 0.0 & 0.0 & 0.0 & 0.0 \\
\hline Philippines & 0.0 & 0.0 & 0.0 & 0.0 & 0.0 \\
\hline Viet Nam & 0.0 & 0.0 & 0.0 & 0.0 & 0.0 \\
\hline Other East Asia \& Pacific & 0.0 & 0.0 & 0.0 & 0.0 & 0.0 \\
\hline South Asia & 2.5 & 0.0 & 2.2 & 0.0 & 0.2 \\
\hline Bangladesh & 0.0 & 0.0 & 0.0 & 0.0 & 1.7 \\
\hline India & 3.4 & 0.0 & 2.9 & 0.0 & 0.0 \\
\hline Other South Asia & 0.1 & 0.0 & 0.1 & 0.0 & 0.3 \\
\hline Middle East \& North Africa & 0.0 & 0.0 & 0.0 & 0.0 & 0.0 \\
\hline Morocco & 0.0 & 0.0 & 0.0 & 0.0 & 0.0 \\
\hline Other M. East \& N. Africa & 0.0 & 0.0 & 0.0 & 0.0 & 0.0 \\
\hline Sub-Saharan Africa & 0.0 & 0.0 & 0.0 & 0.0 & 0.0 \\
\hline South Africa & 0.0 & 0.0 & 0.0 & 0.0 & 0.0 \\
\hline Other Sub-Saharan Africa & 0.0 & 0.0 & 0.0 & 0.0 & 0.0 \\
\hline Latin America \& Caribbean & 0.2 & 0.0 & 0.1 & 0.2 & 0.0 \\
\hline Argentina & 0.0 & 0.0 & 0.0 & 0.0 & 0.0 \\
\hline Brazil & 0.7 & 0.0 & 0.3 & 0.0 & 0.0 \\
\hline Other Latin America \& Carib. & 0.0 & 0.0 & 0.0 & 0.3 & 0.0 \\
\hline
\end{tabular}

${ }^{a}$ Forestry, fishing, coal, oil, gas, and minerals

${ }^{\mathrm{b}}$ Intra-EU15 trade is ignored in EU and world trade in calculating trade weights Source: Authors' compilations from the GTAP database Version 6.05 
Table 2: Estimates of services trade barriers, 2001

(percent trade cost equivalents)

\begin{tabular}{lrrrr}
\hline & $\begin{array}{c}\text { Trade } \\
\text { services }\end{array}$ & $\begin{array}{c}\text { Transport } \\
\text { and } \\
\text { logistics } \\
\text { services }\end{array}$ & $\begin{array}{c}\text { Business } \\
\text { services }\end{array}$ & $\begin{array}{c}\text { Other } \\
\text { services }\end{array}$ \\
Region & 0.0 & 2.3 & 9.5 & 15.2 \\
\hline High-income countries & 0.0 & 22.6 & 1.2 & 16.0 \\
Australia \& New Zealand & 0.0 & 22.6 & 1.2 & 16.0 \\
United States & 0.0 & 22.6 & 1.2 & 16.0 \\
Canada & 9.6 & 3.2 & 2.9 & 4.6 \\
Mexico & 1.6 & 0.0 & 0.0 & 0.0 \\
European Union (EU15) & 9.6 & 3.2 & 2.9 & 4.6 \\
EU's 10 new entrants & 0.0 & 0.0 & 6.3 & 0.0 \\
European Free Trade Area & 0.0 & 0.0 & 6.3 & 0.0 \\
Japan & 0.0 & 0.0 & 6.3 & 0.0 \\
Korea \& Taiwan & & & & \\
Hong Kong \& Singapore & & & & \\
& 1.6 & 0.0 & 0.0 & 0.0 \\
Developing countries & 0.0 & 14.5 & 37.4 & 3.7 \\
Eastern Europe \& Central Asia & 0.0 & 0.0 & 0.0 & 0.0 \\
China & 61.3 & 63.9 & 32.1 & 62.2 \\
All other East Asia \& Pacific & 0.0 & 0.0 & 0.0 & 0.0 \\
India & 2.3 & 0.0 & 0.0 & 0.0 \\
All other South Asia & 28.3 & 17.5 & 32.8 & 22.6 \\
Middle East \& North Africa & & & & \\
Sub-Saharan Africa & 13.8 & 10.4 & 8.6 & 5.9 \\
\hline All other Latin America \& Carib & & & & \\
\hline
\end{tabular}

Source: Francois et al. (2005) and Hertel and Keeney (2006) 
Table 3: Changes in sectoral value added from full global trade reform for different developing country regions, by trade-liberalizing component

\begin{tabular}{|c|c|c|c|c|c|}
\hline $\begin{array}{l}\text { Change in sectoral value } \\
\text { added in different regions: }\end{array}$ & $\begin{array}{l}\text { High-income } \\
\text { countries' } \\
\text { agriculture } \\
\text { and food lib. }\end{array}$ & $\begin{array}{l}\text { Developing } \\
\text { countries' } \\
\text { agriculture } \\
\text { and food lib. }\end{array}$ & $\begin{array}{c}\text { All countries' } \\
\text { other } \\
\text { merchandise } \\
\text { trade lib. }\end{array}$ & $\begin{array}{c}\text { All } \\
\text { countries' } \\
\text { services } \\
\text { trade lib. }\end{array}$ & $\begin{array}{c}\text { Total global } \\
\text { goods and } \\
\text { services } \\
\text { trade lib. }\end{array}$ \\
\hline \multicolumn{6}{|l|}{ Primary Agriculture } \\
\hline All developing countries & 6.7 & -2.6 & 0.9 & 0.7 & (1.8) \\
\hline Middle-income countries & 8.3 & -2.1 & 1.4 & 0.4 & $(1.3)$ \\
\hline Low-income countries & 3.8 & -3.5 & 0.2 & 1.2 & $1.6 \quad(3.6)$ \\
\hline E. Europe \& Central Asia & 3.1 & -2.2 & -0.4 & 0.0 & $0.6(-0.5)$ \\
\hline East Asia \& Pacific & 8.1 & -1.5 & 2.6 & 0.5 & $9.6 \quad(5.0)$ \\
\hline South Asia & 2.8 & -4.2 & 0.1 & 1.4 & $0.2(-0.3)$ \\
\hline MiddleEast \& North Africa & 6.1 & -5.1 & 0.3 & 0.2 & $1.5(0.8)$ \\
\hline Sub-Saharan Africa & 5.1 & -4.4 & 0.4 & 1.5 & $2.7 \quad(2.5)$ \\
\hline Latin America \& Carib. & 12.2 & -0.5 & 0.2 & 0.4 & $12.2(-0.3)$ \\
\hline \multicolumn{6}{|l|}{ Processed Food } \\
\hline All developing countries & 3.6 & -1.1 & 1.1 & 0.4 & 4.0 \\
\hline Middle-income countries & 3.3 & -1.9 & 0.9 & 0.2 & 2.5 \\
\hline Low-income countries & 4.5 & 1.3 & 1.5 & 0.8 & 8.3 \\
\hline E. Europe \& Central Asia & 5.4 & -7.0 & 0.8 & 0.2 & -0.5 \\
\hline East Asia \& Pacific & 1.0 & 5.1 & 2.7 & 0.1 & 8.9 \\
\hline South Asia & 9.4 & -7.5 & 2.0 & 1.0 & 4.9 \\
\hline MiddleEast \& North Africa & 6.0 & -6.8 & 1.6 & 0.2 & 1.0 \\
\hline Sub-Saharan Africa & 4.9 & -5.6 & 1.5 & 1.8 & 2.6 \\
\hline Latin America \& Carib. & 3.4 & -0.6 & 0.0 & 0.3 & 3.1 \\
\hline \multicolumn{6}{|l|}{ Non-ag Primary } \\
\hline All developing countries & 0.2 & 0.3 & 0.6 & 0.5 & 1.6 \\
\hline Middle-income countries & 0.0 & 0.4 & 1.5 & 0.2 & 2.1 \\
\hline Low-income countries & 0.7 & 0.1 & -1.3 & 1.3 & 0.8 \\
\hline E. Europe \& Central Asia & -0.2 & 0.9 & 1.7 & -0.3 & 2.1 \\
\hline East Asia \& Pacific & 0.9 & 0.3 & -0.9 & 0.6 & 0.9 \\
\hline South Asia & 1.6 & 0.1 & -8.7 & 1.4 & -5.6 \\
\hline Middle East \& North Africa & 0.1 & 0.4 & 2.9 & -0.3 & 3.0 \\
\hline Sub-Saharan Africa & 0.3 & -0.2 & 4.0 & 2.8 & 6.9 \\
\hline Latin America \& Carib. & -0.9 & -0.1 & 1.2 & 0.5 & 0.7 \\
\hline \multicolumn{6}{|l|}{ Other Manufacturing } \\
\hline All developing countries & -0.5 & 0.3 & 1.3 & 0.4 & 1.5 \\
\hline Middle-income countries & -0.5 & 0.4 & 0.6 & 0.3 & 0.8 \\
\hline Low-income countries & -0.6 & 0.1 & 3.5 & 0.8 & 3.8 \\
\hline E. Europe \& Central Asia & -0.5 & 0.7 & -2.0 & -0.3 & -2.0 \\
\hline East Asia \& Pacific & -0.3 & 0.2 & 5.3 & 0.3 & 5.5 \\
\hline South Asia & -0.6 & 0.5 & -0.9 & 1.8 & 0.8 \\
\hline Middle East \& North Africa & -0.4 & 0.5 & -0.9 & -0.7 & -1.5 \\
\hline Sub-Saharan Africa & -1.0 & 1.0 & -3.4 & 2.5 & -1.0 \\
\hline Latin America \& Carib. & -0.6 & 0.2 & -1.6 & 0.5 & -1.5 \\
\hline
\end{tabular}

${ }^{a}$ Numbers in parentheses show percentage change in non-agricultural value added as a consequence of full global trade reform. Source: Authors' GTAP-AGR model simulations 
Table 4: Changes in agricultural (and non agricultural) value added from full global trade reform for different regions, by trade-liberalizing component

(percent)

\begin{tabular}{|c|c|c|c|c|c|}
\hline $\begin{array}{l}\text { Change in agricultural value } \\
\text { added in different regions: }\end{array}$ & $\begin{array}{c}\text { High- } \\
\text { income } \\
\text { countries' } \\
\text { agriculture } \\
\text { and food lib. }\end{array}$ & $\begin{array}{l}\text { Developing } \\
\text { countries' } \\
\text { agriculture } \\
\text { and food } \\
\text { lib. }\end{array}$ & $\begin{array}{c}\text { All countries' } \\
\text { other } \\
\text { merchandise } \\
\text { trade lib. }\end{array}$ & $\begin{array}{c}\text { All } \\
\text { countries' } \\
\text { services } \\
\text { trade lib. }\end{array}$ & $\begin{array}{l}\text { Total global } \\
\text { goods and } \\
\text { services trade } \\
\text { liberalization }\end{array}$ \\
\hline High-income countries & -23.4 & 0.6 & -0.2 & 0.2 & $\begin{array}{ll}-22.8 & (0.2)\end{array}$ \\
\hline Australia \& New Zealand & 16.2 & 0.5 & 0.7 & 0.2 & $17.7 \quad(1.3)$ \\
\hline United States & -15.0 & 0.9 & -0.3 & 0.2 & $-14.2(-0.5)$ \\
\hline Canada & -6.9 & 0.2 & 0.5 & 0.3 & $-5.9(-1.3)$ \\
\hline Mexico & -8.7 & 0.1 & -0.8 & 0.2 & $-9.2(-0.2)$ \\
\hline European Union (EU15) & -26.6 & 0.4 & -0.5 & 0.2 & $-26.5(-0.6)$ \\
\hline EU's 10 new entrants & -1.8 & 1.8 & -0.5 & 0.1 & $-0.4 \quad(0.9)$ \\
\hline European Free Trade Area & -37.4 & 5.4 & 0.4 & 0.1 & $-31.6(-2.8)$ \\
\hline Japan & -55.5 & -0.2 & 0.3 & 0.1 & $-55.3(2.6)$ \\
\hline Korea \& Taiwan & -41.0 & 0.0 & 1.0 & 0.2 & $-39.8 \quad(6.5)$ \\
\hline Hong Kong \& Singapore & 3.0 & 0.5 & 0.4 & 1.1 & $5.0(10.5)$ \\
\hline Developing countries & 6.7 & -2.6 & 0.9 & 0.7 & 5.7 (1.8) \\
\hline Middle-income countries & 8.3 & -2.1 & 1.4 & 0.4 & (1.3) \\
\hline Low-income countries & 3.8 & -3.5 & 0.2 & 1.2 & $1.6 \quad(3.6)$ \\
\hline E. Europe \& Central Asia & 3.1 & -2.2 & -0.4 & 0.0 & $0.6(-0.5)$ \\
\hline Russia & 3.0 & -4.5 & -0.2 & 0.0 & $-1.6(-0.5)$ \\
\hline Other E. Europe \& C. Asia & 3.1 & -1.6 & -0.4 & 0.1 & $1.2(-0.4)$ \\
\hline East Asia \& Pacific & 8.1 & -1.5 & 2.6 & 0.5 & $9.6 \quad(5.0)$ \\
\hline China & 8.8 & -1.8 & 3.4 & 0.6 & 11.0 \\
\hline Indonesia & 2.3 & 0.1 & -0.1 & 0.2 & (4.1) \\
\hline Philippines & 0.9 & -6.4 & 1.4 & 0.0 & $-4.0 \quad(5.3)$ \\
\hline Viet Nam & 2.5 & 0.9 & 1.8 & 0.1 & $5.4(27.5)$ \\
\hline Other East Asia \& Pacific & 12.8 & 2.1 & -0.8 & 0.1 & $14.2(7.0)$ \\
\hline South Asia & 2.8 & -4.2 & 0.1 & 1.4 & $0.2(-0.3)$ \\
\hline Bangladesh & 1.7 & -4.7 & 1.6 & 0.0 & $-1.5 \quad(1.5)$ \\
\hline India & 2.6 & -4.9 & -0.2 & 1.8 & $-0.7(-0.4)$ \\
\hline Other South Asia & 4.0 & -0.7 & 1.0 & 0.2 & $4.6(-0.1)$ \\
\hline Middle East \& North Africa & 6.1 & -5.1 & 0.3 & 0.2 & $1.5(0.8)$ \\
\hline Morocco & 10.6 & -11.3 & 1.6 & 0.1 & (7.2) \\
\hline Other M. East \& N. Africa & 5.8 & -4.6 & 0.2 & 0.2 & $(0.5)$ \\
\hline Sub-Saharan Africa & 5.1 & -4.4 & 0.4 & 1.5 & (2.5) \\
\hline South Africa & 7.8 & -2.6 & 0.1 & 1.2 & (1.9) \\
\hline Other Sub-Saharan Africa & 4.8 & -4.6 & 0.5 & 1.7 & $2.4 \quad(2.9)$ \\
\hline Latin America \& Caribbean & 12.2 & -0.5 & 0.2 & 0.4 & $12.2(-0.3)$ \\
\hline Argentina & 14.3 & 3.8 & 0.5 & 0.6 & $19.2(0.7)$ \\
\hline Brazil & 39.1 & 1.9 & 0.7 & 0.8 & $42.5(-0.6)$ \\
\hline Other Latin America \& Carib. & 13.3 & -2.8 & 0.4 & 0.3 & $11.2(-0.9)$ \\
\hline World & -4.5 & -1.4 & 0.5 & 0.5 & $-4.9(0.6)$ \\
\hline
\end{tabular}

${ }^{\mathrm{a}}$ Numbers in parentheses show percentage change in non-agricultural value added as a consequence of full global trade reform.

Source: Authors’ GTAP-AGR model simulations 
Table 5: Changes in sectoral value added from own, other countries' and global full trade liberalization of all goods and services, selected developing countries and SubSaharan Africa

(percent)

\begin{tabular}{|c|c|c|c|c|}
\hline & $\begin{array}{c}\text { Own } \\
\text { unilateral } \\
\text { Liberalization }\end{array}$ & $\begin{array}{c}\text { Other } \\
\text { developing } \\
\text { countries' } \\
\text { liberalization }\end{array}$ & $\begin{array}{l}\text { High-income } \\
\text { countries' } \\
\text { liberalization }\end{array}$ & $\begin{array}{l}\text { Total global } \\
\text { liberalization }\end{array}$ \\
\hline \multicolumn{5}{|l|}{ Brazil } \\
\hline Primary Agriculture & 1.6 & 1.9 & 38.9 & 42.5 \\
\hline Processed Food & 0.5 & -0.5 & 22.8 & 22.9 \\
\hline Non-agric Primary & 3.5 & 0.9 & -9.7 & -5.4 \\
\hline Other Manufacturing & -2.3 & -0.4 & -2.4 & -5.1 \\
\hline \multicolumn{5}{|l|}{ Argentina } \\
\hline Primary Agriculture & 1.2 & 3.4 & 14.6 & 19.2 \\
\hline Processed Food & 0.5 & 0.7 & 4.5 & 5.7 \\
\hline Non-agric Primary & 1.8 & 2.0 & -2.0 & 1.8 \\
\hline Other Manufacturing & -1.7 & -0.4 & 0.9 & -1.2 \\
\hline \multicolumn{5}{|l|}{ China } \\
\hline Primary Agriculture & -2.2 & 1.4 & 11.9 & 11.0 \\
\hline Processed Food & 1.7 & 1.0 & 1.7 & 4.5 \\
\hline Non-agric Primary & 1.8 & -0.6 & 0.6 & 1.7 \\
\hline Other Manufacturing & 2.0 & 1.1 & 1.6 & 4.7 \\
\hline \multicolumn{5}{|l|}{ Indonesia } \\
\hline Primary Agriculture & -2.4 & 2.0 & 2.9 & 2.5 \\
\hline Processed Food & 0.1 & 10.0 & 2.4 & 12.5 \\
\hline Non-agric Primary & -0.3 & -0.9 & -0.7 & -1.9 \\
\hline Other Manufacturing & 2.0 & 0.3 & 4.1 & 6.4 \\
\hline \multicolumn{5}{|c|}{ Sub-Saharan Africa (excl. S. Africa) } \\
\hline Primary Agriculture & -2.4 & -0.4 & 5.2 & 2.4 \\
\hline Processed Food & -2.7 & -0.2 & 5.1 & 2.2 \\
\hline Non-agric Primary & 6.2 & -0.2 & 0.5 & 6.6 \\
\hline Other Manufacturing & 2.3 & -1.2 & -2.9 & -1.8 \\
\hline \multicolumn{5}{|l|}{ India } \\
\hline Primary Agriculture & -4.1 & -0.5 & 3.8 & -0.7 \\
\hline Processed Food & -7.3 & 1.2 & 13.4 & 7.3 \\
\hline Non-agric Primary & -7.6 & 0.0 & 1.8 & -5.8 \\
\hline Other Manufacturing & 0.9 & -0.7 & 0.1 & 0.3 \\
\hline \multicolumn{5}{|l|}{ Bangladesh } \\
\hline Primary Agriculture & -2.7 & -1.4 & 2.6 & -1.5 \\
\hline Processed Food & -5.5 & 0.3 & -0.7 & -5.9 \\
\hline Non-agric Primary & -5.7 & -1.3 & -0.4 & -7.4 \\
\hline Other Manufacturing & 8.3 & -2.2 & 1.1 & 7.2 \\
\hline
\end{tabular}

Source: Authors' GTAP-AGR model simulations 
Table 6: Changes in agricultural value added from own, other countries' and global full trade liberalization of agricultural and non-agricultural products, selected developing countries and Sub-Saharan Africa

(percent)

\begin{tabular}{|c|c|c|c|c|c|c|c|c|c|}
\hline & \multicolumn{3}{|c|}{ Agricultural liberalization } & \multicolumn{3}{|c|}{$\begin{array}{l}\text { Non-agricultural } \\
\text { liberalization }\end{array}$} & \multicolumn{3}{|c|}{ Total liberalization } \\
\hline & Own & $\begin{array}{c}\text { Other } \\
\text { developing } \\
\text { countries }\end{array}$ & $\begin{array}{c}\text { High - } \\
\text { income } \\
\text { countries }\end{array}$ & Own & $\begin{array}{c}\text { Other } \\
\text { developing } \\
\text { countries }\end{array}$ & $\begin{array}{c}\text { High - } \\
\text { income } \\
\text { countries }\end{array}$ & Own & $\begin{array}{l}\text { Other } \\
\text { countries }\end{array}$ & All countries ${ }^{a}$ \\
\hline Brazil & -0.6 & 2.5 & 39.1 & 2.2 & -0.6 & -0.2 & 1.6 & 40.9 & $42.5(-0.6)$ \\
\hline Argentina & -0.2 & 4.0 & 14.3 & 1.4 & -0.6 & 0.3 & 1.2 & 18.0 & $19.2(0.7)$ \\
\hline China & -2.0 & 0.2 & 8.8 & -0.2 & 1.2 & 3.1 & -2.2 & 13.2 & $11.0(4.3)$ \\
\hline Indonesia & -2.1 & 2.2 & 2.3 & -0.3 & -0.3 & 0.6 & -2.4 & 4.9 & 2.5 (4.1) \\
\hline Sub-Saharan Africa, ex. SA & -4.7 & 0.1 & 4.8 & 2.3 & -0.5 & 0.4 & -2.4 & 4.8 & $2.4 \quad(2.9)$ \\
\hline India & -5.2 & 0.2 & 2.6 & 1.1 & -0.8 & 1.3 & -4.1 & 3.5 & $-0.7(-0.4)$ \\
\hline Bangladesh & -4.7 & 0.0 & 1.7 & 2.0 & -1.3 & 1.0 & -2.7 & 1.2 & $-1.5 \quad(1.5)$ \\
\hline \multicolumn{10}{|c|}{$\begin{array}{l}\text { If zero national agric \& food tariffs in the following countries, } \\
\text { effects there are as follows: }\end{array}$} \\
\hline$\overline{\text { Argentina }^{\mathrm{b}}}$ & 34.4 & 4.3 & 16.0 & 0.3 & -0.6 & 0.3 & 34.7 & 20.0 & $54.7(6.9)$ \\
\hline Sub-Saharan Africa, ex. SA & 0.0 & -0.2 & 4.5 & 2.2 & -0.5 & 0.4 & 2.2 & 4.3 & $6.5(3.7)$ \\
\hline India & 0.0 & -0.3 & 2.7 & 1.2 & -0.8 & 1.3 & 1.2 & 2.9 & $4.1(-0.2)$ \\
\hline Bangladesh & 0.0 & 0.0 & 1.7 & 2.1 & -1.4 & 1.0 & 2.1 & 1.2 & $3.3(1.2)$ \\
\hline
\end{tabular}

\footnotetext{
${ }^{a}$ Numbers in parentheses show percentage changes in non-agricultural value added as a consequence of full global trade reform.

${ }^{b}$ In Argentina's case, we first altered the GTAP database not only to set all its agricultural and food import tariffs to zero but also to simulate the imposition from 2002 of export taxes, set at 20 percent for cereals, oilseeds and livestock products, 10 percent for other (including non agricultural) primary products, and 5 percent for other processed food products and all other manufacturing; then from that new base we estimated the effects of full unilateral reform.
}

Source: Authors’ GTAP-AGR model simulations 
Table 7: Developing countries' shares of global output, value added and exports before and after full global liberalization of goods and services, by product

(percent)

\begin{tabular}{|c|c|c|c|c|c|c|}
\hline & \multicolumn{6}{|c|}{ Developing Countries’ share of global } \\
\hline & \multicolumn{2}{|c|}{$\underline{\text { Value of Output }}$} & \multicolumn{2}{|c|}{$\underline{\text { Value Added }}$} & \multicolumn{2}{|c|}{ Value of Exports } \\
\hline & Base & $\begin{array}{c}\text { Full } \\
\text { liberalization }\end{array}$ & Base & $\begin{array}{c}\text { Full } \\
\text { liberalization }\end{array}$ & Base & $\begin{array}{c}\text { Full } \\
\text { liberalization }\end{array}$ \\
\hline Rice & 71 & 92 & 75 & 93 & 66 & 73 \\
\hline Wheat & 72 & 73 & 54 & 70 & 23 & 34 \\
\hline Coarse grains & 63 & 63 & 49 & 63 & 29 & 33 \\
\hline Fruit \& veg. & 71 & 73 & 72 & 75 & 47 & 54 \\
\hline Oilseed products & 52 & 52 & 52 & 59 & 50 & 61 \\
\hline Sugar & 53 & 59 & 54 & 60 & 67 & 75 \\
\hline Cotton & 73 & 75 & 70 & 76 & 48 & 60 \\
\hline Other crops & 51 & 51 & 47 & 48 & 60 & 59 \\
\hline Beef \& sheepmeat & 36 & 41 & 37 & 45 & 17 & 47 \\
\hline Pork \& poultry & 46 & 47 & 56 & 58 & 24 & 21 \\
\hline Wool & 80 & 81 & 34 & 35 & 20 & 29 \\
\hline Dairy products & 31 & 31 & 74 & 76 & 9 & 13 \\
\hline Other food products & 31 & 31 & 24 & 24 & 32 & 31 \\
\hline All agric and food & 43 & 45 & 46 & 49 & 35 & 40 \\
\hline Non-agric primary & 61 & 61 & 62 & 62 & 72 & 72 \\
\hline Other manufacturing & 26 & 25 & 21 & 21 & 24 & 26 \\
\hline Services & 16 & 16 & 14 & 15 & 18 & 18 \\
\hline
\end{tabular}

Source: Authors' GTAP-AGR model simulations 
Table 8: Share of production exported and of consumption imported, world and developing countries, before and after full global liberalization of goods and services, by product

\begin{tabular}{|c|c|c|c|c|c|c|c|c|}
\hline & \multicolumn{6}{|c|}{ Share of production exported } & \multirow{2}{*}{\multicolumn{2}{|c|}{$\begin{array}{c}\begin{array}{c}\text { Share of } \\
\text { consumption } \\
\text { imported }\end{array} \\
\begin{array}{c}\text { Developing } \\
\text { countries }\end{array} \\
\end{array}$}} \\
\hline & \multicolumn{2}{|r|}{ World } & \multicolumn{2}{|c|}{$\begin{array}{l}\text { High-income } \\
\text { countries }\end{array}$} & \multicolumn{2}{|c|}{$\begin{array}{l}\text { Developing } \\
\text { countries }\end{array}$} & & \\
\hline & Base & $\begin{array}{c}\text { Full } \\
\text { liberalization } \\
\end{array}$ & Base & $\begin{array}{c}\text { Full } \\
\text { liberalization } \\
\end{array}$ & Base & $\begin{array}{c}\text { Full } \\
\text { liberalization } \\
\end{array}$ & Base & $\begin{array}{c}\text { Full } \\
\text { liberalization }\end{array}$ \\
\hline Rice & 3.3 & 10.8 & 3.8 & 35.7 & 3.1 & 8.5 & 3.2 & 4.2 \\
\hline Wheat & 16.9 & 19.1 & 45.6 & 46.1 & 5.4 & 9.0 & 14.2 & 15.9 \\
\hline Coarse grains & 13.7 & 15.2 & 26.1 & 27.7 & 6.3 & 8.0 & 10.4 & 12.0 \\
\hline Fruit \& veg. & 10.6 & 11.4 & 19.5 & 19.8 & 7.0 & 8.3 & 3.4 & 4.2 \\
\hline Oilseed products & 15.1 & 20.4 & 15.5 & 16.7 & 14.8 & 23.7 & 15.0 & 24.0 \\
\hline Sugar & 5.1 & 9.7 & 3.5 & 6.0 & 6.5 & 12.3 & 5.2 & 6.5 \\
\hline Cotton & 20.7 & 20.9 & 40.7 & 33.4 & 13.5 & 16.7 & 17.1 & 17.4 \\
\hline Other crops & 18.9 & 21.2 & 15.3 & 17.7 & 22.3 & 24.5 & 10.6 & 15.1 \\
\hline Beef \& sheepmeat & 6.8 & 9.4 & 8.8 & 8.5 & 3.2 & 10.7 & 4.6 & 5.0 \\
\hline Pork \& poultry & 7.7 & 9.2 & 10.9 & 13.6 & 3.9 & 4.1 & 4.0 & 5.6 \\
\hline Wool & 16.2 & 16.6 & 65.3 & 60.8 & 4.1 & 6.0 & 9.4 & 10.3 \\
\hline Dairy products & 6.2 & 8.1 & 8.2 & 10.3 & 1.7 & 3.4 & 6.4 & 8.2 \\
\hline Other food products & 10.2 & 11.3 & 10.1 & 11.3 & 10.5 & 11.3 & 7.7 & 9.8 \\
\hline All agric and food & 9.6 & 11.7 & 11.1 & 12.8 & 7.7 & 10.2 & 6.8 & 8.7 \\
\hline Non-agric primary & 30.7 & 31.4 & 22.2 & 22.5 & 36.1 & 37.0 & 14.6 & 15.8 \\
\hline Other manufacturing & 28.4 & 30.6 & 29.0 & 30.3 & 26.7 & 31.6 & 26.6 & 32.5 \\
\hline Services & 3.5 & 3.7 & 3.4 & 3.6 & 4.0 & 4.2 & 4.9 & 5.2 \\
\hline
\end{tabular}

Source: Authors' GTAP-AGR model simulations 
Table 9: Self-sufficiency by product and region, 2001 baseline and after full liberalization of goods and services globally

(production as a percent of production plus net imports)

\begin{tabular}{|c|c|c|c|c|c|c|c|c|c|c|c|c|}
\hline & \multicolumn{2}{|c|}{$\begin{array}{l}\text { High-Income } \\
\text { countries }\end{array}$} & \multicolumn{2}{|c|}{$\begin{array}{l}\text { Developing } \\
\text { countries }\end{array}$} & \multicolumn{2}{|c|}{$\begin{array}{c}\text { Sub-Saharan } \\
\text { Africa }\end{array}$} & \multicolumn{2}{|c|}{$\begin{array}{l}\text { Latin America } \\
\text { \& Carib. }\end{array}$} & \multicolumn{2}{|c|}{ China } & \multicolumn{2}{|c|}{ India } \\
\hline & Base & Full Lib & Base & Full Lib & Base & Full Lib & Base & Full Lib & Base & Full Lib & Base & Full Lib \\
\hline Rice & 99 & 60 & 100 & 105 & 86 & 72 & 96 & 94 & 101 & 116 & 103 & 106 \\
\hline Wheat & 131 & 123 & 91 & 92 & 48 & 50 & 91 & 90 & 98 & 99 & 103 & 106 \\
\hline Coarse grains & 107 & 106 & 96 & 96 & 101 & 101 & 112 & 115 & 103 & 107 & 101 & 101 \\
\hline Fruit \& veg. & 87 & 84 & 104 & 105 & 125 & 126 & 127 & 135 & 101 & 102 & 99 & 96 \\
\hline Oilseed products & 98 & 98 & 100 & 100 & 94 & 104 & 129 & 133 & 81 & 59 & 95 & 80 \\
\hline Sugar & 98 & 90 & 101 & 107 & 109 & 125 & 121 & 143 & 84 & 81 & 102 & 103 \\
\hline Cotton & 108 & 98 & 96 & 99 & 232 & 289 & 101 & 101 & 98 & 99 & 90 & 91 \\
\hline Other crops & 85 & 87 & 115 & 112 & 139 & 139 & 141 & 127 & 114 & 105 & 107 & 107 \\
\hline Beef\&sheepmeat & 100 & 95 & 99 & 106 & 100 & 108 & 103 & 119 & 97 & 96 & 106 & 153 \\
\hline Pork \& poultry & 100 & 101 & 100 & 98 & 98 & 94 & 105 & 102 & 100 & 99 & 99 & 95 \\
\hline Wool & 124 & 119 & 95 & 95 & 104 & 106 & 110 & 107 & 87 & 91 & 88 & 84 \\
\hline Dairy products & 102 & 102 & 95 & 95 & 83 & 82 & 98 & 98 & 93 & 90 & 100 & 100 \\
\hline Other food prod & 98 & 98 & 103 & 102 & 100 & 98 & 109 & 109 & 103 & 103 & 115 & 115 \\
\hline All agric\&food & 98 & 97 & 101 & 102 & 104 & 104 & 110 & 114 & 100 & 101 & 101 & 101 \\
\hline Non-ag primary & 68 & 68 & 132 & 134 & 172 & 174 & 131 & 134 & 96 & 95 & 79 & 77 \\
\hline Other manuf. & 98 & 99 & 97 & 99 & 80 & 81 & 87 & 85 & 106 & 108 & 98 & 101 \\
\hline Services & 100 & 100 & 99 & 99 & 98 & 98 & 100 & 99 & 98 & 98 & 100 & 100 \\
\hline
\end{tabular}

Source: Authors’ GTAP database 6.05 calculations and GTAP-AGR model simulations 
Table 10: Contributions to regional and global agricultural value added, to global agricultural trade, and to global economic welfare, of fully removing agricultural subsidies and tariffs globally, by policy instrument

\begin{tabular}{|c|c|c|c|c|c|c|c|c|c|}
\hline & \multicolumn{7}{|c|}{ (percent) } & & \\
\hline & \multicolumn{3}{|c|}{$\begin{array}{l}\text { High-income countries' } \\
\text { liberalization of: }\end{array}$} & \multicolumn{3}{|c|}{$\begin{array}{l}\text { Developing countries' } \\
\text { liberalization of: }\end{array}$} & \multicolumn{3}{|c|}{ All countries' liberalization of: } \\
\hline & $\begin{array}{l}\text { Export } \\
\text { subsidies }\end{array}$ & $\begin{array}{l}\text { Domestic } \\
\text { support }\end{array}$ & $\begin{array}{l}\text { Import } \\
\text { market } \\
\text { access }\end{array}$ & $\begin{array}{l}\text { Export } \\
\text { subsidies }\end{array}$ & $\begin{array}{l}\text { Domestic } \\
\text { support }\end{array}$ & $\begin{array}{l}\text { Import } \\
\text { market } \\
\text { access }\end{array}$ & $\begin{array}{l}\text { Export } \\
\text { subsidies }\end{array}$ & $\begin{array}{l}\text { Domestic } \\
\text { support }\end{array}$ & $\begin{array}{l}\text { Import } \\
\text { market } \\
\text { access }\end{array}$ \\
\hline \multicolumn{10}{|l|}{ Contribution to value added: } \\
\hline$\%$ gain Developing countries & 10 & 45 & 106 & 0 & 0 & -61 & 10 & 45 & 45 \\
\hline$\%$ loss World & -0.3 & 46 & 31 & 0 & 0 & 23 & -0 & 46 & 54 \\
\hline \multicolumn{10}{|l|}{$\begin{array}{l}\text { Contribution to world } \\
\text { agricultural trade }\end{array}$} \\
\hline \multicolumn{10}{|l|}{$\begin{array}{l}\text { Contribution to economic } \\
\text { welfare: } \\
\text { (equivalent variation in income): }\end{array}$} \\
\hline High-income countries & 5 & 6 & 78 & 0 & 0 & 11 & 5 & 6 & 89 \\
\hline Developing countries & -10 & 2 & 84 & 0 & -1 & 25 & -10 & 1 & 109 \\
\hline World & 2 & 5 & 79 & 0 & 0 & 14 & 2 & 5 & 93 \\
\hline
\end{tabular}

Source: Authors' GTAP-AGR model simulations 
Table 11: Contribution of different products to the global welfare gain from agricultural and food sector reform, and from all sectors' reform

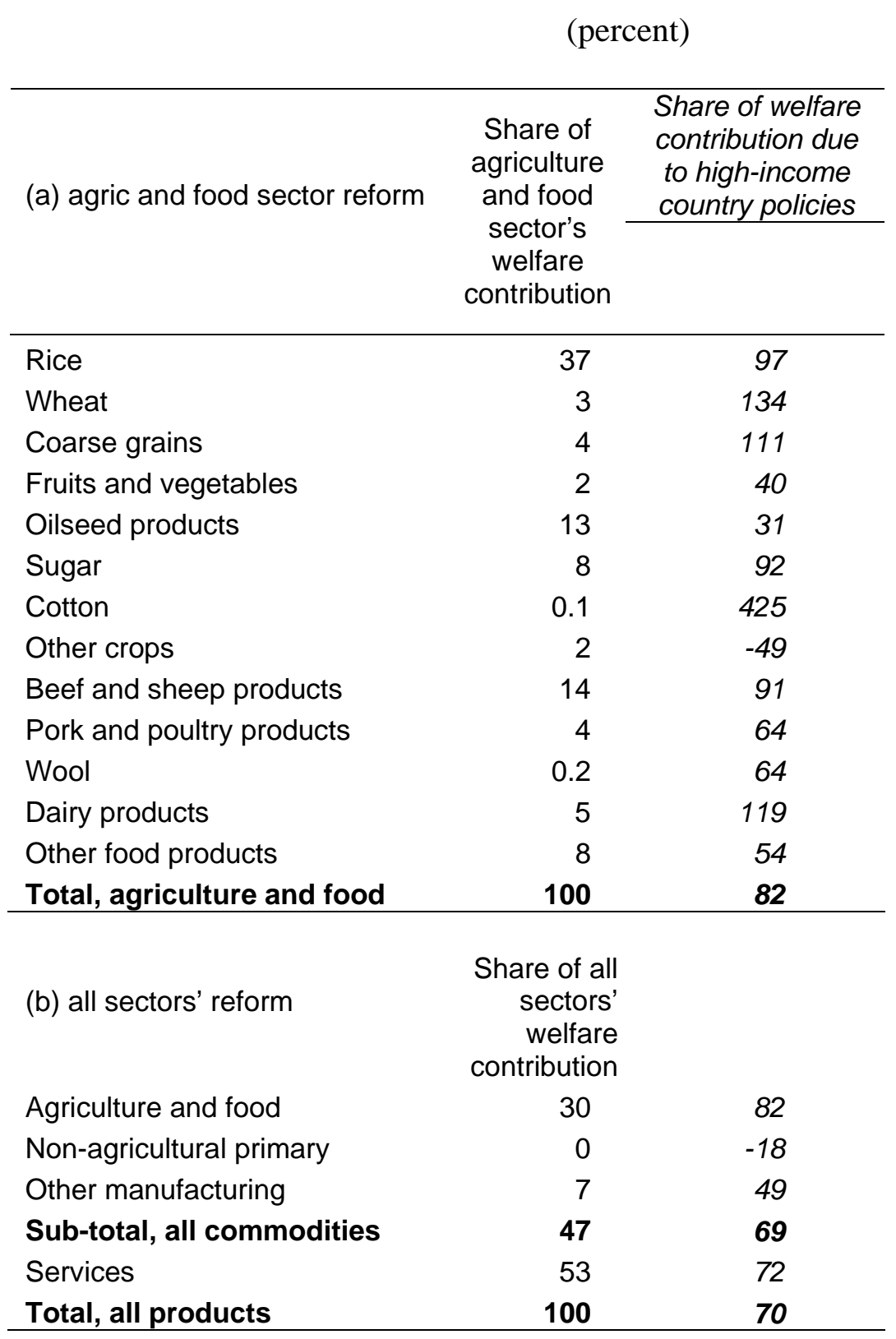

Source: Authors’ GTAP-AGR model simulations 


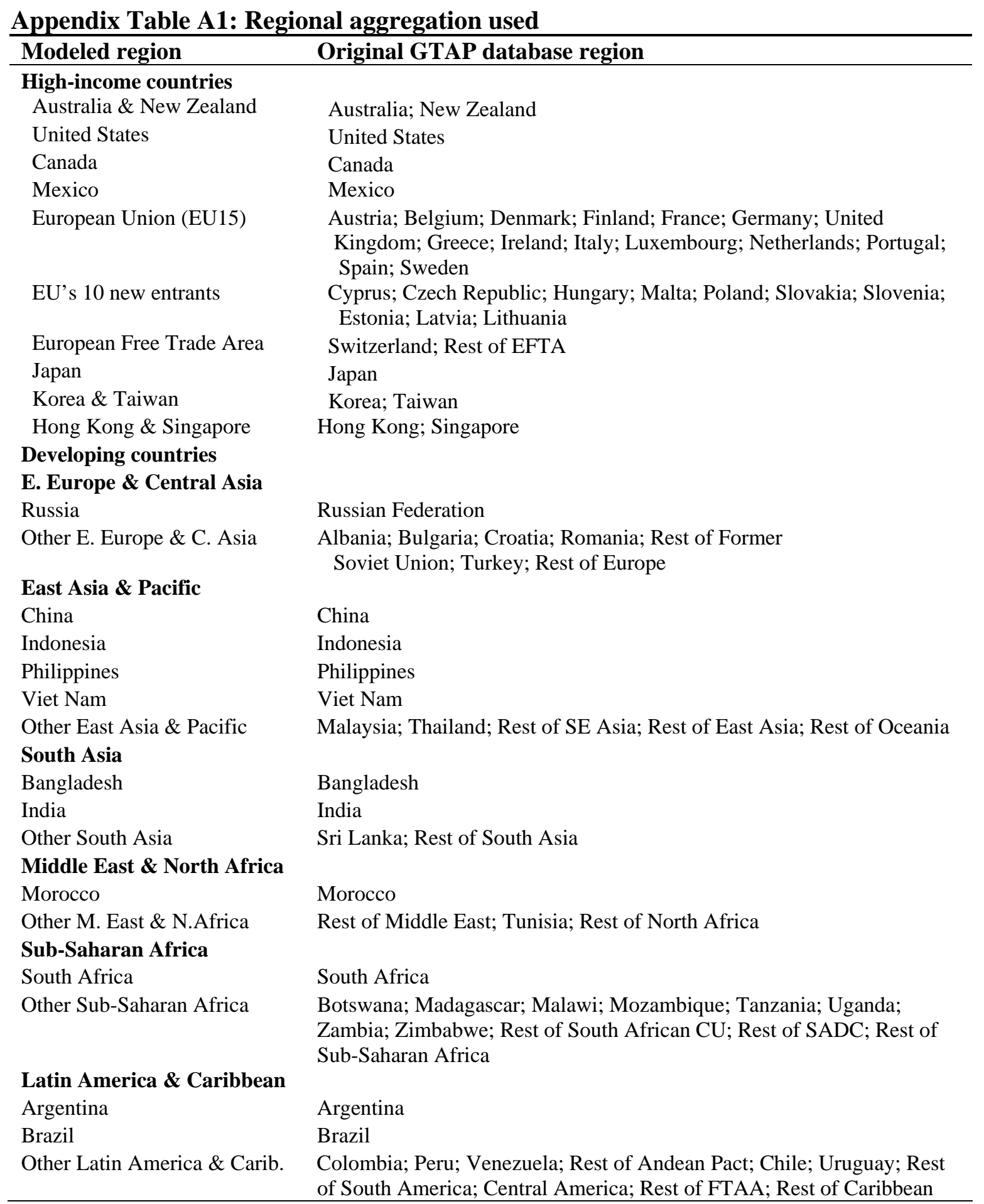

Post-simulation aggregated developing country regions, by income classification Middle-income countries: China, Argentina, Brazil, Other Latin America \& Carib., Russia, Other E. Europe \& C. Asia, Morocco, Other M. East \& N. Africa, South Africa Low-income countries: Indonesia, Philippines, Viet Nam, Other East Asia \& Pacific, India, Bangladesh, Other South Asia, Other Sub-Saharan Africa. 
Appendix Table A2: Sectoral aggregation used

\begin{tabular}{|c|c|c|}
\hline $\begin{array}{l}\text { Post-simulation } \\
\text { commodity aggregation }\end{array}$ & CGE Modeled sector & $\begin{array}{l}\text { Original GTAP database } \\
\text { sectors }\end{array}$ \\
\hline \multirow{2}{*}{ Rice } & Paddy rice & $\mathrm{Pdr}$ \\
\hline & Processed rice & Pcr \\
\hline Wheat & Wheat & Wht \\
\hline Coarse grains & Cereals & Gro \\
\hline Fruit \& vegetables & Fruits \& vegetables & $v_{-} f$ \\
\hline \multirow[t]{2}{*}{ Oilseed products } & Oilseeds & Osd \\
\hline & Oils \& fats & Vol \\
\hline \multirow[t]{2}{*}{ Sugar } & Sugar raw & c_b \\
\hline & Sugar processed & Sgr \\
\hline Cotton & Plant-based fibers & $\mathrm{Pfb}$ \\
\hline Other crops & Crops nec & Ocr \\
\hline \multirow{2}{*}{ Beef \& sheep products } & Livestock & $\mathrm{Ctl}$ \\
\hline & Meat products & $\mathrm{Cmt}$ \\
\hline \multirow[t]{2}{*}{ Pork \& poultry products } & Other animal products & Oap \\
\hline & Other meat products & Omt \\
\hline Wool & Wool \& silk-worm & Wol \\
\hline \multirow{2}{*}{ Dairy products } & Milk raw & Rmk \\
\hline & Dairy & Mil \\
\hline \multirow[t]{2}{*}{ Other food products } & Other food products & Ofd \\
\hline & Beverages \& tobacco & b_t \\
\hline \multirow[t]{2}{*}{ Other primary } & Fishing & Fsh \\
\hline & Other primary & frs, coa, oil, gas, omn \\
\hline \multirow[t]{3}{*}{ Other manufacturing } & Textiles \& W. apparel & tex, wap, lea \\
\hline & Manuf. of primary & $\begin{array}{l}\text { lum, ppp, p_c, crp, nmm, } \\
\text { i_s, nfm, fmp }\end{array}$ \\
\hline & Other manufactures & mvh, otn, ele, ome, omf \\
\hline \multirow[t]{4}{*}{ Services } & Utility \& construction & ely, gdt, wtr, cns \\
\hline & Trade \& transport & trd, otp, wtp, atp \\
\hline & $\begin{array}{l}\text { Communic. \& } \\
\text { financial }\end{array}$ & cmn, ofi, isr, obs \\
\hline & Other services & ros, osg, dwe \\
\hline
\end{tabular}

\section{Post-simulation aggregated sectors}

Primary Agriculture: Paddy rice, Processed rice, Wheat, Cereals, Fruits \& vegetables, Oilseeds, Sugar raw, Sugar processed, Fibers, Crops nec, Livestock, Other animal products, Milk raw, Wool \& silk-worm.

Processed Food: Meat products, Other meat products, Dairy, Other food products, Oils \& fats, Beverages \& tobacco.

Non-agric Primary: Fishing, Other primary.

Other Manufacturing: Textiles \& Wearing apparel, Manufacture of primary, Other manufactures. Services: Utility \& construction, Trade \& transport, Communication \& financial, Other services 